\title{
Medicine and science in a new medical-surgical context: the Royal College of Surgery of Barcelona (1760-1843)
}

\begin{abstract}
Taking the Royal College of Barcelona (1760 -1843) as a case study this paper shows the development of modern surgery in Spain initiated by Bourbon Monarchy founding new kinds of institutions through their academic activities of spreading scientific knowledge. Antoni Gimbernat was the most famous internationally recognised Spanish surgeon. He was trained as a surgeon at the Royal College of Surgery in Cadiz and was later appointed as professor of the Anatomy in the College of Barcelona. He then became Royal Surgeon of King Carlos IV and with that esteemed position in Madrid he worked resiliently to improve the quality of the Royal colleges in Spain. Learning human body structure by performing hands-on dissections in the anatomical theatre has become a fundamental element of modern medical education. Gimbernat favoured the study of natural sciences, the new chemistry of Lavoisier and experimental physics in the academic programs of surgery. According to the study of a very relevant set of documents preserved in the library, the so-called "juntas literarias", among the main subjects debated in the clinical sessions was the concept of human beings and diseases in relation to the development of the new experimental sciences. These documents showed that chemistry and experimental physics were considered crucial tools to understand the unexplained processes that occurred in the diseased and healthy human body and in a medico-surgical context. It is important to stress that through these manuscripts we can examine the role and the reception of the new sciences applied to healing arts.
\end{abstract}

\section{KEYWORDS}

Royal College of Surgery; chemistry; experimental physics; enlightenment. 


\section{Introduction}

The Barcelona Royal College of Surgery was the second college created in Spain (Albiol 1999; Martínez-Vidal 1999; Ferrer 1963). It was founded in 1760 by the Bourbon monarchy during the Spanish enlightenment in a country (Catalonia ${ }^{1}$ ) occupied by Bourbon military forces (Astrain 1996a; Astrain 1996b). The development of modern surgery was determined by an increasing demand for well-trained medical personnel able to attend to the soldiers on the several fronts opened in Europe ${ }^{2}$.

It is worth remembering that from 1714, all the universities in Catalonia- including the University of Barcelona - were closed by the Bourbon monarchy for political reasons - and a new university was built in the remote town of Cervera (Castellví 2002). Nevertheless, the only institution where an academic degree related to health could be obtained in the principality was the Royal College of Surgery of Barcelona. Indeed, the medical students from the University of Cervera had to practise anatomy in that College.

Later on, at the end of the eighteenth century and the early part of the nineteenth, surgeons, physicians and pharmacists were gathered together in the so-called "Facultad Reunida". During the following years this joint venture of surgeons and physicians had a lot of formal problems but when University of Barcelona was re-established and its rights were returned in the middle of the nineteenth century, surgeons and physicians were rejoined in the Faculty of Medicine. This emphasised the importance and the special conditions of physician-surgeons trained previously in the Royal colleges of surgery in Spain.

\footnotetext{
1 The War of the Spanish Succession (1705-1714) resulted in the revocation of Catalonia's traditional autonomy and privileges. When King Carlos II died without a successor in 1700, Catalonia supported the claim of a member of the Austrian branch of the Habsburg dynasty, while the rest of Spain generally supported the French Bourbon claimant, Felipe V. Following the final surrender of Catalan troops on September 11, 1714, the Nueva Planta decrees by King Felipe V banned all the main Catalan political institutions and imposed military-based rule over the region. Currently, Catalonia is an autonomous community in Spain.

${ }^{2}$ In other European countries a formal body of knowledge emerged as a consequence of French Revolution-Napoleonic era. See BLANCO, R.L. (1974).
} 


\section{New surgery required corpses and patients to be studied}

In 1773, according to the Oración inaugural (Antoni Gimbernat 1773), in the lesson which opened the new academic year at the College, Professor Gimbernat emphasised the importance of learning medicine beside the patient as well as repeated practice with the dissection of corpses, adding that the anatomy was the most noble of all sciences and arts.

Learning medicine beside the patient, a tradition started in Bologna by Tadeo Alderotti (1223-1295) and in other Italian universities, led to the development of the so-called clinical sessions or lessons. Lain Entralgo, in his important research, analyses the gradual conversion of the interpretation of the medical records. The observatio of the individual cases were changing from a simple explanation to the explicatio or interpretation of symptoms (Laín Entralgo 1963: 40-41). In the late seventeenth and early eighteenth centuries along with the observatio, another possible way to describe the disease was the Sydenham's history. Thomas Sydenham (1624-1689) introduced the concept of "specific medicine" in which each disease was associated with an effective specific therapy. While acute diseases were described biologically, the chronic diseases were considered biographically. Finally, Hermann Boerhaave (1668-1738) in Leiden ultimately ended up setting the clinical pattern that prevailed throughout the eighteenth century. The medical history should give a description of the subject (name, age, social status, constitution), past history, data on the treatment established and, in case of death, the inspection of the body with the corresponding pathological examination (Laín Entralgo 1950).

So, the academic program developed in the new colleges of surgery was different from the traditional corporative education for surgeons. Learning human bodily structure by performing hands-on dissections in the anatomical theatre had become a fundamental element of modern medical education. For that reason the Royal College of Surgery of Barcelona was erected next to the Hospital Santa Creu, an age-old institution of health founded in 1401 (Massons 2002; Usandizaga 1964). On the one hand students had to practice in the hospital and moreover the hospital provided patients and corpses to be studied. So, the hospital provided the raw material to be studied in a training program based on patient observation (Pérez-Pérez 2004). These new medicalsurgeons trained there were not only interested in therapeutics, but 
wanted to know as much as possible about the parts of the body and their functions, the body's physiology and, when faced with illness, its pathology, being in professional competition with physicians.

In Barcelona during the Enlightenment, the coexistent health institutions both traditional and newly created ones often came into conflict to defend their own interests (Zarzoso 2004: 72-97) ${ }^{3}$. Some of the disputes were as a result of the supply of corpses for anatomy. As soon as the Royal College of Surgery of Barcelona was inaugurated, the responsibility of teaching anatomy at the College was transferred to Antoni Gimbernat Arbós (Cambrils 1734 - Madrid 1816) who became the teacher of anatomy and anatomic dissector at the Royal College of Surgery of Barcelona from 1761 to 1774 . In addition, by the Royal Order of $10^{\text {th }}$ July 1765, he was nominated surgeon of the Hospital de Santa Creu (Salcedo 1928: 174; Ferrer 1968: 112; Arechaga 1977; Riera 1976: 151-165; Bujosa 1983: 395-399).

The appointment of Gimbernat as a head of anatomy coincided with an increase in the practice of anatomy for training purposes and a greater demand for corpses. This fact was even more important from 1768 when the students from University of Cervera were impelled to pursue the anatomy practices at the College. Furthermore, the continued practice of anatomy in Barcelona, enhanced by his presence at the College, aroused suspicion among the population, especially among people admitted to the hospital who could be delivered for dissection in case of death. The archives of the Hospital of Santa Creu i Sant Pau preserve this document: a poem about the popular perception of people about to be anatomised after death (Pérez-Pérez 2004).
"Hijos del Santo Hospital, pues en el medicinados fuimos, y ya sepultados nos vemos en un corral dad ya fin a nuestro Mal con vuestro piadoso anhelo

\footnotetext{
${ }^{3}$ All the aspects related to the professional practices of physicians in Catalonia had been well studied and published by the Spanish historian Alfons Zarzoso. Also you can see (2006), L'exercici de la medicina a la Catalunya de la Il-lustració, Manresa, Publicacions de l'Arxiu d'Història de les Ciències de la Salut (PAHCS).
} 


\section{a Dios pedidle cristianos" 4}

During the time spent by Gimbernat in England, he had the opportunity to attend classes taught by the prestigious English surgeon John Hunter (1728-1793). The lessons of Hunter were not in any manual or treatise. To learn their contents it was required to attend his courses ${ }^{5}$. At this time, the practice of anatomy in private schools was very common in England because private schools were better equipped than universities. While in regular schools of surgery the students had the unique option to watch their teachers operate on the corpse, the private courses allowed students to practice on the bodies. The second half of the eighteenth century was the golden era of schools of anatomy. Nevertheless, in England this private training continued until 1831, after which state hospitals and the University of London opted for a more rigorous education than the lucrative private practice (Porter 1995: 472473).

Gimbernat discovered a new anatomical structure: the lacunar ligament, also known as Gimbernat's Ligament ${ }^{6}$. Gimbernat, in the private courses taught by John Hunter had the opportunity to show his new operative procedure. One practical application of this structure was a new method for operating on the crural (or inguinal) hernia. It is worth remembering that the new operative method on the crural hernia was

\footnotetext{
${ }^{4}$ Fragment of the "Lamentos y dolorosos clamores que dan desde el Purgatorio las Almas de los pobres difuntos sepultados en el corralete del Hospital General de Santa Cruz de Barcelona", Arxiu Històric de l'Hospital de la Santa Creu i Sant Pau, in Documentos curiosos del Hospital 1527-1959. [Translated by the author not textually] Sons of the Holy Hospital/because we were entered there/ Now buried in a "corral" [cemetery]/ Put and end to our suffering/with your pious desire/Christians pray to God.

5 Through his son we know that Gimbernat had written several booklets in English corresponding to 93 Hunterian lessons received. Unfortunately, the notebooks and manuscripts are not currently available and their existence remains in the testimony of his son Agustí (Agustí Gimbernat 1828). The notes corresponding to lesson number 80 in $25^{\text {th }}$ April 1777 summarise the famous episode in which Gimbernat gave a demonstration of his new method and Hunter publicly gave him his approval.

${ }^{6}$ This part of the body is defined in the Anatomy of Human Body (Henry Gray, 1918) as follows; "the lacunar ligament is that part of the aponeurosis of the Obliquus externus which is reflected backward and lateralward, and is attached to the pectineal line. It is about $1.25 \mathrm{~cm}$. long, larger in the male than in the female, almost horizontal in direction in the erect posture, and of a triangular form with the base directed lateralward. Its base is concave, thin, and sharp, and forms the medial boundary of the femoral ring. Its apex corresponds to the pubic tubercle. Its posterior margin is attached to the pectineal line, and is continuous with the pectineal fascia. Its anterior margin is attached to the inguinal ligament. Its surfaces are directed upward and downward".
} 
performed for the first time on the dissecting table of the College of Surgery of Barcelona in 1768, and also at the Hospital de Santa Creu, where Gimbernat operated on two women suffering from this condition. This procedure was published in 1793 in Madrid (Antoni Gimbernat 1793), twenty-five years after it had been first practiced in the College of Barcelona. The new method for operating on crural hernia was translated into English by Thomas Beddoes (1795) $)^{7}$. Joseph Townsend mentioned it in a Guide to Health (Townsend 1796) and later it was translated into German (1817) ${ }^{8}$ and French (1827) (Salcedo 1928; Calbet and Corbella 1982: 48-49). Beddoes, in the introductory note to the translation said that English surgeons had little account of the works of their foreign counterparts and emphasises the superiority of Gimbernat's operative method as a reason that convinced him to translate it.

Traditional historiography had considered the work of Antonio Gimbernat as one of the more internationally recognised Spanish contributions to the history of surgery of the eighteenth century (Salcedo 1928; Usandizaga 1964; Cardoner 1936; Pi-Sunyer 1936). For that reason this surgeon should be mentioned in the context of a new medicalsurgical concept of medicine and science. The influence of this professor was notorious in the Royal College of Surgery of Barcelona and in the following years would become the most authoritative representative of Spanish surgical reform during the Enlightenment. Later on he became Royal Surgeon of King Carlos IV and with that esteemed position in Madrid, he worked resiliently improving the quality of the Royal Colleges in Spain.

\section{The "Juntas Literarias" as a new procedure to spread science}

In this setting, and as it was similarly being introduced in other enlightenment scientific institutions belonging to this period (Zarzoso

\footnotetext{
7 This translation was entitled New Method of Operating for the Femoral Hernia translated from the Spanish of Don Antonio de Gimbernat, surgeon of the King of Spain to which are added, with plates, by the Translator [Thomas Beddoes], queries respecting a safer method of performing inoculation; and the Treatment of certain Fevers, Londres, J. Johnson.

8 Entitled Neue Methode den Schenkelbruch zu operiren, Nürnberg, Steinischen Buchhandlung. Translated by the German surgeon SCHREGER, Bernhard Gottlob (17661825).
} 
2004), for instance societies and academies ${ }^{9}$, a new form of transmission of knowledge as well as a new method of teaching were proposed in the regulations of the colleges of surgeons in Spain. The rules of the Colleges of Surgery in Spain decided to hold the so called "junta literaria" (PérezPérez 2007; Vicente 1982; Usandizaga 1956). These were clinical sessions or lessons in which experts were invited to discuss several aspects related to the medical histories of patients admitted to the Hospital of Santa Creu, among other generic subjects related to the healing arts. The college offered these academic sessions in addition to the normal academic studies for the different degrees involved. The rules of the Spanish colleges of surgery favoured these kind of academic activities in which a dissertation was read periodically and, after that, critically assessed in a public session in front of both the students and the board of professors of the college. So both professors and students attended the dissertations that were read periodically by the professor in front of the audience. Then, in the following session, another member of the College Board assigned by the Vice-Chairman was in charge of preparing a critical assessment, read in public session again, plus a critical writing about the dissertation. At the end of the session a short written assessment or comment was given by each professor member of the board. All these documents, about 200 manuscripts and the corresponding assessments, are available in the archives and constitute important evidence of the scientific activity at the Royal College of Barcelona $^{10}$. It is important to stress that through these manuscripts the role and the reception of the new sciences applied to healing arts will be examined.

The "Juntas Literarias" were handwritten in Spanish, despite being reviewed for possible publication during the first half of the nineteenth century and were never published. On average, from 1796 to 1806 at least one session was held each month from October to June. Each dissertation had the same expository scheme: introduction, explanation and conclusion. Each session had the same structure: dissertation/critical assessment/general assessment by the professors. The

\footnotetext{
${ }^{9}$ For instance in the Academia Médico-Práctica and also in the Real Academia de Ciencias y Artes de Barcelona, both institutions devoted to science and located in the city of Barcelona.

${ }^{10}$ These documents have been preserved and digitalized in the Ancient Book Collection at the University of Barcelona.
} 
number of interventions and the participation of each member of the College Board were well balanced between its members (Pérez-Pérez 2007).

\section{The role of the Chemistry in the healing arts}

The post-Lavoisier new chemistry was applied to the mysterious processes concerning life and was considered useful knowledge for improving the healing art. Chemistry has not only been a science of ideas and discoveries but also marvellous in its uses. In the beginning of the nineteenth century chemistry had already achieved its own language: a new nomenclature, several gases had been characterised, the theory of combustion had been announced and experimentation in the laboratory experiments were common scientific practice. Modern medicine depends heavily on compounds synthesised in the chemical laboratory to fight disease (Levere 2001). In Spain, all of these innovative events could take place in a new scenario: the Royal College of Surgery. Due to the regulations promoted by Antoni Gimbernat in 1795 (Ordenanzas ... 1975), chemistry and experimental physics were included in the academic programs of the Spanish Royal Colleges of Surgery.

According to the documentation preserved in the archives, it is clear that chemistry was present in the dissertations expounded at the Royal College of Surgeons of Barcelona. Chemistry should be considered as a professional, liberal, and useful activity in the continuum from research papers, reviews, textbooks, and its proper diffusion (Knight 2000: 187-188). In the sessions held at the Royal College of Surgery of Barcelona some dissertations were presented with the intention of illustrating the reception of chemistry for medico-surgical purposes. The first reference to chemistry found in the college's files is dated 1797 about removing gallstones from the urinary bladder using carbonic acid (Artigas 1797). Artigas, in this dissertation, emphasises the importance of the new knowledge provided by chemistry, quoting those who had made it possible: Lavoisier, Fourcroy, Priestley and also the Spaniard Pedro Gutiérrez Bueno ${ }^{11}$, among others.

\footnotetext{
${ }^{11}$ On the one hand Pedro Gutiérrez Bueno was the Spanish translator (1798) of the work on the new nomenclature developed by Lavoisier, Morveau, Fourcroy and Bertholet, on the other hand Juan Manuel Munárriz translated Lavoisier's crucial work in 1798 (2 vol.). These works were used as textbooks in the Spanish Royal Colleges of Surgery.
} 
At the end of eighteenth century, being interested in anatomy, aerostatics, surgery and chemistry at the same time was completely acceptable. As a result of the French Revolution, the publication of the Annales de Chimie was interrupted for three years, but when it reappeared in the prologue of the first issue Annales de Chimie stated that chemistry was in debt to the aerostatic balloons. In England, John Sheldon, surgeon and disciple of William Hunter (Bynum and Porter 1985) and professor of anatomy of Thomas Beddoes (Standfield 1984: 16-17), according to the History of Aeronautics in Great Britain (Hodgson 1924: 114), directed his enquiries to improving, simplifying and perfecting the aerostatic balloon. To make observations of the sound and movement at the atmosphere, Sheldon built his aerostatic balloon and was the first English man who travelled by air in 1784. In France the air balloons symbolised the freedom of man in the face of nature, as well as the union between science and the state. In this sense, a Spanish engraving which illustrates the explanations about how this artefact could be built ${ }^{12}$ (Figure 1) show the relationship between the knowledge and the state in this sentence:

"The Mongolfier brothers found/ how to cross outside/; Pilatres and Arlandes tried it/ as did Charles and Robert without Palinuro:/ But if they were sent by the winds / (...) I say to you that the present engraving represents/ all that Spain achieved and France barely tried to do." [Fragment translated by the author into English].

The possibilities opened for the development of aerostatics machines and the use of aerostatic balloons for medical purposes were subjects of controversy at the public sessions "Juntas Literarias" of the Royal College of Surgery of Barcelona. The novelty was compared with the expectation opened by electricity that had been a subject of controversy at the College, as will be seen later. On 8th May 1800 the dissertation "Uses of Aerostatic Balloons applied to medicine" was presented in a

\footnotetext{
${ }^{12}$ From the original text in Spanish: "Los dos Hermanos Montgolfiers hallaron/ el modo de sulcar el ayre puro;/ Pilatres, y el de Arlandes le ensayaron/ qual Charles, y Robert sin Palinuro: /Màs, si à aquellos los vientos les mandaron, ly yo, que tu les mandes te aseguro, / ya la Estampa presente representa, /que España logra lo que Francia intenta. [Anonymous] [subsequent to 1780], Regio Faetonte aerostático, Zaragoza, en la oficina de Blas Miedes, plate 50 x $35 \mathrm{~cm}$. Learning and Research Resources Center. Ancient Book Collection. University of Barcelona.
} 
public session by professor Bover (Bover 1800). Antoni San German, the reviewer professor in charge of presenting the critical assessment of the dissertation on the use of aerostatic balloon disagreed with Bover (San German 1800). San German took advantage of the occasion to make his personal opinion about the mass media in an interesting final evaluation of the work presented by his colleague:

"[...] the journals are incentives which generally attract our wills with insignificant and extravagant things. If people who are not especially bright ever hear other people debating or refuting them, they can be influenced by this kind of thing. That has been the author's healthy aim and for this reason he should be eulogised." [Translated into English by the author] ${ }^{13}$

In my opinion, in this case we are faced with an instructive and strategic example of instrumental uses of "Juntas Literarias" as public sessions able to show the audience the pros and cons of the use of balloons for medical purposes, a subject that without doubt provoked controversy, expectation and anticipation in the Spanish enlightened society in those days.

\section{The body begins to be seen as a laboratory for experimentation}

Other sessions performed at the Royal College made explicit reference to the affinity concept. It was in Montpellier where Jean Antoine Chaptal (1756-1832) first defined he affinity concept as a chemical action, a force inherent to the molecules of matter (organic and inorganic) which bodies exerted on each other from an imperceptible distance, equivalent to the attraction of mass in physics (Chaptal 1816). Moreover, in living beings, affinity was modulated by the laws of vitality, mainly forces such as sensitivity and irritability. The development of the study of airs (gasses) crossed the boundaries between chemistry, physics, and medicine. The so called "natural philosophers" studied problems that led them into chemistry but also into domains outside the normal scope of chemical practice (Holmes 2000).

\footnotetext{
${ }^{13}$ From the original text in Spanish: "Los papeles periódicos son unos alicientes que atraen comunmente nuestras voluntades con vagatelas, extravagancias, y si éstas no las oyen disputar y refutar los de cortos alcances, se dejan llevar después ciegamente de ellas. Éste ha sido el saludable fin de nuestro autor, y por lo mismo repito que es elogiable".
} 
All these theoretical concepts were present in the dissertations performed at the college of Barcelona regarding pathology and therapeutics. For example, some authors were convinced that there must be a substance able to dissolve gallstones as well as some kind of tumours by chemical affinity. As a result of this theoretical approach, surgical activity was moved from exclusively external to internal. The substances exerted their effects on the targeted organ through the stomach by chemical reactions, for instance the dissolving of gallstones in the urinary bladder. So, the explanation of the prescribed treatments by chemistry takes place in the human body. The ontological status of the body begins to be seen as a true laboratory for experimentation. Furthermore, the same idea of chemical affinity was behind the concept of neutralisation. When two compounds were able to be combined, the result acquires a different characteristic from that which occurs when they are displayed separately. In this theoretical context it was argued that the syphilis virus could have a chemical affinity for mercury and be neutralised by it, according to a dissertation read in the Royal College of Surgery of Barcelona (Borràs 1798).

With these epistemological changes, the next question was to identify the factors responsible for organic disorders. Did the organ actually become ill by itself or did the disease appear as a result of the action of some vital principia -phosphorous, oxygen, caloric, electricity, among others-? With this question in mind, the professors of the College were thinking in terms of solidism versus pneumatic chemistry. According to J.B.T. Baumes' Essai d'un systeme chimique de la science de l'home (Nimes, 1798), some diseases could be the result of an imbalance in the concentration of several chemical substances. Also, erysipelas could be caused by an increase in caloric, inflammations by an excess of oxygen, convulsions by an excess of electrical fluid and so on. The Spanish chemist and pharmacist Francesc Carbonell Bravo, criticised the nosology of Baumes in his thesis dissertation presented in Montpellier in 1801. A nosology according to which many of the common diseases could be explained, depending on some principle ingredients (oxygen, hydrogen, electricity, caloric, and so on) were in excess or deficiency. It is important to note that the disagreement of Carbonell was very well known by the professors of the college, as it was extensively commented on in two sessions held only a few months later, in July 1801, (Bas and Cibat, respectively). It is worth mentioning that 
the full text of the Carbonell's dissertation was published into Spanish in 1805.

But the benefit of chemistry applied to the healing art was not evident to everyone. Some professors of the College thought that these kinds of sciences alone (chemistry mathematics, and so on) were not enough to know the human body. Francesc Borràs i Montaner, professor and also one of the anatomical dissectors of the college, in the foreword of his work Treatise of pathology theoretical and practice (1820), pointed out that he voluntarily had resigned to explain the phenomena by chemical laws exposing and due to that decision some people would not read him. Borràs said that the human body was not a "pharmaceutical laboratory" and that "the majority of young people wasted their time talking about chemistry, forgetting that their aim must be the human machine" (Borràs 1820).

\section{Electricity: from chemistry to experimental physics}

Neither the notions of Haller on irritability and sensitivity (Brazier 1984; Roberts 1999) ${ }^{14}$ nor the Stahl's vitalism had conceived the possibility that electricity itself could produce the animation of the bodies. In the middle of the eighteenth century, the abbot and professor of experimental physics Jean-Antoine Nollet (1700 - 1770) defined electricity as something with both irritating and stimulating characteristics simultaneously ${ }^{15}$. The electrical fluid and electricity were analogous to light and fire. For this reason, some scientists thought that the origins of all of these elements should be the same. The nature of electricity was initially included among the chemical principia of the body (Seligardi 2001: 181-208). Nevertheless, after Alessandro Volta's experiments electricity was considered an inherent force of nature. The experiments presented in the Royal Society by Henry Cavendish (1771-1772), or the public demonstrations by John Hunter using torpedo fish lead to thinking that electricity could be innate in living beings (Schaffer 2004). In 1791, Luigi Galvani, professor of Obstetrics in the Italian university of Bologna, described how the muscle of a frog prepared for dissection was

\footnotetext{
14 In 1745, Haller had anonymously published a review of studies on the German electricity in Bibliothèque Raisonnée des Ouvrages des Savants de l'Europe, quoted by ROBERTS, Lissa (1999).

${ }^{15}$ NOLLET, Jea -Antoine (1746), Essai sur l'electricité des corps, París, Freres Guerin. Translated into Spanish in 1747 by Joseph Vázquez y Morales.
} 
able to experience contractions when the crural nerve of this amphibian was connected to the metallic arc ${ }^{16}$. The new observed phenomenon was denominated "galvanism", and "galvanic fluid" being a substance of the same nature as the "nervous fluid".

The expectation opened by the nature of electricity and its application to the healing art was present at the Royal College of Surgery of Barcelona according to the dissertations read in its meetings. At least two of them should be mentioned: "On galvanism" (Bover 1802) read in public session in 1802 and "On muscle fibres" (Bover 1806) read in 1806.

In 1802, "On galvanism" was written as an extensive review about galvanism where the novelties of electricity were expounded to the audience reviewing the main characters that had made its development possible (among others, Galvani and Volta). It should be noted that in this dissertation the expectations offered by the galvanism were compared to the expectations offered by Jenner's vaccine. Nothing was unusual in this association because at least two issues of a periodic journal with the title Du Galvanisme et Vaccine were published in 1803 in Paris. Moreover, the famous romantic poet Lord Byron (1788-1824) associated the vaccine with the new chemistry of the airs and also with the galvanic phenomena. Quoted by Roy Porter (1994), thinking of Edward Jenner (1749-1823) and Elisha Perkins (1741-1799), the poet composed these lines mentioning cow pox, the metallic tractors, galvanism and the gas together:

"What varied wonders tempt us as they pass!

The Cow-pox, Tractors, Galvanism, Gas

In turns appear to make the vulgar stare,

In the swoll'n bubble bursts--and all is air.

Death's captains, Death's disciples."

"On galvanism" presented as a dissertation at the Royal College of Surgery of Barcelona explained the development of "metallic tractors" developed by Perkins and his son in 1798. They used electrified metallic needles in order to relieve several kinds of health disorders "drawing off

\footnotetext{
${ }^{16}$ GALVANI, Luigi (1791), De viribus electricitatis in motu musculari commentarius, a De Bononiensi Scientarum et Artium Instituto atque Academia Comentarii, vol. VII, Bononiae, Ex Typographia Instituti Scientiarum, edició digital a cura de Marco Bresadola, P. Fezzi.
} 
the noxious electrical fluid that lay at the root of suffering" (Perkins 1800).

After the evaluation of Galvani's experiments, in the same dissertation the coexistence of two different types of death is proposed: the animal death in relation to the chemical principles that conforms the living bodies, and the death of the vitality related with the vital principles that animate the living beings. In this context, electricity was intimately associated with vitality. Living beings had been used to identify the effects of the electricity on the animal economy. For that purpose and in spite of the ethical and political problems, the use of corpses of people condemned to capital punishment has been documented. Alfred Smee, surgeon of the St. Bartholomew Hospital of London, defended the theory that the bodies could regulate the intrinsic electricity they had themselves. He was the object of a lot of criticism for this statement. Marilyn Butler, expert in the English Romanticism cultural movement, thought that these debates may have been a good source of inspiration for Mary Shelley, author of the famous Frankenstein novel (1818) (Morus 1998: 126-128, 147).

Both Galvani and Volta, observing the same phenomena, the muscular contraction in frogs prepared for their dissection, reached different conclusions. It was the so called Galvani-Volta controversy and the subject of the dissertation "On muscle fibres" presented at the College in 1806. Galvani, physician and physiologist, thought that there was some kind of animal electricity inherent to the organisation of the living body and responsible for muscular contraction. The lack of an electrometer able to measure the minimal amount of electricity involved in this physiological phenomena made it difficult to demonstrate. From 1800 to 1805 Giovanni Aldini reproducing Galvani's experiments was able to produce signals of electricity in animals without the aid of metals, which corroborated the hypothesis that living bodies could be considered as true batteries able to produce and to accumulate electricity. However, the physicist Alessandro Volta using an apparatus developed by himself, the so called Volta's battery, was able to induce muscular contractions experimentally. This fact reaffirmed the possible external origin of the phenomenon.

The Galvani -Volta controversy was exposed in the public session "On muscle fibres" at the Royal College of Surgery of Barcelona and that dissertation demonstrated, in detail, the structure of Volta's battery applied to treatments. The reception of the theories of Galvani by the 
professors of the College was divided. Some of them showed to be more in agreement with Volta's postulates, others with Galvani, others with the chemical changes proposed by Alexander Humboldt, and others expressed their scepticism.

In order to demonstrate the great importance of the literary meetings "Juntas Literarias" celebrated at the College. The statement by Professor Antoni Cibat Arnauto (1770 - 1812) in the preface of his work Elements of Experimental Physics (Cibat 1804, vol. 1) is worth mentioning. From 1798 to 1792 , Cibat studied surgery at the college of Barcelona. After that, he went to Scotland and obtained his PhD at the Marischal College in Aberdeen ${ }^{17}$ and then he returned to the Royal College of Barcelona and was professor of Experimental Physics from 1797 to 1807 (Riera 1976: 177-178; Cabrera 1990: 182; Calbet and Corbella 1981; Guereña 1998; Massons 2003: 117-120) According to Cibat he had started his research on the effects of the electricity in living beings and by extension on human beings at the Royal School of Surgery of Barcelona some years before.

In the dissertations read at the College of Barcelona, at least ten manuscripts can be found on that subject. Galvanism was a subject of interest from 1798, coinciding with the arrival of professor Cibat at the College, until 1806 when the activities of the Royal College were interrupted due to the French War (Table I). The surgeon and doctor Cibat, as a professor of Experimental Physics at the Royal College of Surgery of Barcelona, presented at least two dissertations in 1798 and in $1799^{18}$, respectively, on the usefulness of the electricity in the healing art.

Table I:

\footnotetext{
17 List of Diplomas M.D. granted by the Marischal College from January 1792 to January 1793. M397/5/8. Special Libraries and Archives King's College. Aberdeen University (Scotland).

${ }^{18}$ Cibat i Arnautó, Antoni (1798), Memoria o sea ensayo el trismus traumático, 12 de julio de 1798. Ms. 55, Bundle 7, University of Barcelona; (1799), Solución a las Objeciones que se hicieron a la memoria o ensayo sobre el trismus traumático que leyó en este Sabio Congreso en el año próximo pasado de 1798 y experimentos que corroboran el modo con que discurrí en aquella. Ms. 67, Bundle 8, University of Barcelona. [12 $2^{\text {th }}$ July 1799].
} 
Clinical dissertations related to galvanism read at the Royal College of Surgery of Barcelona from 1796 to 1806

\begin{tabular}{|c|c|c|c|}
\hline Author & Document & $\begin{array}{c}\text { Title } \\
\text { Scientfic session }\end{array}$ & Year \\
\hline Prof. A. Cibat & Dissertation & Sobre el trismus traumático & 1798 \\
\hline Prof. J.A. Capdevila & Comment & Sobre el trismus traumático & 798 \\
\hline Prof. A. Cibat & Dissertation & $\begin{array}{l}\text { Solución a las objeciones al } \\
\text { trismus traumático }\end{array}$ & 1799 \\
\hline Prof. D. Bover & Comment & $\begin{array}{l}\text { Sobre las soluciones a las } \\
\text { objeciones del trismus traumático }\end{array}$ & 1799 \\
\hline Prof. D. Bover & Dissertation & Discurso sobre el galvanismo & 1802 \\
\hline Prof. F. Junoy & Com & $\begin{array}{l}\text { Reflexiones a la observación de } D \text {. } \\
\text { Bover }\end{array}$ & 1802 \\
\hline Prof. A. Cibat & Dissertation & $\begin{array}{l}\text { Continuación de los ensayos } \\
\text { experimentales con convulsiones }\end{array}$ & 1806 \\
\hline Prof. A. San German & Comment & $\begin{array}{l}\text { De la memoria sobre las } \\
\text { convulsiones }\end{array}$ & 1806 \\
\hline Prof. D. Bover & Dissertation & Sobre la fibra muscular & 1806 \\
\hline Prof. J. Torner & Comment & $\begin{array}{l}\text { De la memoria sobre la fibra } \\
\text { muscular }\end{array}$ & 1806 \\
\hline
\end{tabular}

These ten documents contain some practical aspects related to electricity applied to healing art and as well as some theoretical parts contextualising this new and controversial corpus of knowledge. Extracted from his textbook Elements of Experimental Physics, Cibat and his colleagues had tried to reproduce the crucial experimental works performed by Galvani, Volta, Aldini, Humboldt and others in his laboratory . In spite of Cibat being a defender of Galvani's postulates he specifies the difficulties with the achievement of the results obtained by his predecessors. Cibat and his counterparts tried to reproduce the same experiments, trying to verifying his works at the laboratory, unsuccessfully.

\section{Conclusions}

The current knowledge in biomedicine seems to arise exclusively from the study of the genetic code, understood as "book of life". However, in the eighteenth century, surgeons and doctors applied different metaphors referring the primary source of knowledge. For instance, the medical members of Barcelona Medical Practice Academy called the observation of the number of cases of each disease "the alphabet of Medicine", surely 
following the nosological program of Thomas Sydenham. Nevertheless, the medical surgeons trained in the new Royal Colleges of Surgery considered the human body as a book to learn what it was and what it means to be alive. Anatomical knowledge obtained through observation, usually on the body and also from clinical experiences provided the opportunity to extract different reflections in order to advance knowledge of the art of healing. The clinical and the anatomical amphitheatre were the two main stages of knowledge and practice.

The role of the Spanish First Surgeon (and disciple of John Hunter) Antoni Gimbernat in the development of modern surgery in Spain must be stressed. He promoted, from his privileged position in Madrid, a new set of rules for the Spanish Royal Colleges that included chemistry and experimental physics as required training for medical surgeons, as well as the importance of the practice and the study of patients and bodies for the advancement of knowledge.

The complexity of the reception of the post-Lavoisier new chemistry in a medico-surgical context has been shown according to the primary sources preserved in the library of the University of Barcelona. At the end of the eighteenth and beginning of the nineteenth centuries, there was a debate on how to harmonise the new knowledge coming from chemistry with the effective concepts on the human body. This debate occurred just when the legitimisation of medical surgery was being consolidated. In this setting, chemistry was instrumental knowledge in the understanding of observed phenomena that occurred in healthy human bodies, as well as in diseases, with respect to anatomical, physiological, pathological and therapeutic knowledge.

The emergence of experimental physics was in parallel with the development of the new chemistry of Lavoisier. Since chemistry and experimental physics were included in the academic programs of the Spanish colleges of surgery this kind of knowledge was considered a crucial tool in order to debate and to understand the unexplained processes that took place in the healthy as well as the diseased human body.

According to the subjects presented in the weekly sessions held at the college, the professors had up-to-date scientific knowledge having been acquainted with the new features and publications coming mainly from France and England. But that news was not received passively. The new information arriving was reworked in order to be applied to the healing art. 
Finally, learning medicine beside the patient led to the development of the so-called clinical sessions or lessons. It should be stressed that the literary meetings should be considered as scientific communication practices as well as a strategy of exchanging experiences - addressed primarily to the students of the school, although these sessions were open to other interested members of the public. This activity of diffusion of knowledge could therefore be regarded as a forum from which professional legitimisation could be obtained by a peerreview process in front of all members of the College Board.

\section{References}

New Method of Operating for the Femoral Hernia translated from the Spanish of Don Antonio de Gimbernat, surgeon of the King of Spain to which are added, with plates, by de Translator [Thomas Beddoes], queries respecting a safer method of performing inoculation; and the Treatment of certain Fevers, 1795, Londres, J. Johnson.

Neue Methode den Schenkelbruch zu operiren, Nürnberg, Steinischen Buchhandlung, 1817. Translated by the German surgeon SCHREGER, Bernhard Gottlob (1766-1825).

Ordenanzas de S.M. que deben observarse por el Real Colegio de Cirugía de Barcelona Cuerpo de cirugía militar, Colegios subalternos y cirujanos del Principado de Catalunya, Madrid, 1795.

ALBIOL MOLNÉ, R. (1999), Pere Virgili (1699-1776). Fundador dels Reials Col.legis de Cirurgia d'Espanya. Barcelona, Fundació Uriach 1838.

ARÉCHAGA MARTÍNEZ, Juan (1977) "Biografía científica de Antonio Gimbernat", Medicina e Historia, 66: 7-26.

ARTIGAS, Francesc (1797), Observación sobre un cálculo en la vejiga urinaria curado por el ácido carbónico, 16 de noviembre de 1797, Ms. 45, bundle 6, UB.

ASTRAIN GALLART, Mikel. (1996),"El Protomedicato y la profesión quirúrgica española en el siglo XVIII", Dynamis, 16, 135-150.

ASTRAIN GALLART, M. (1996) Barberos, cirujanos y gente de mar. La sanidad naval y la profesión quirúrgica en la España ilustrada, Madrid, Ministerio de Defensa.

BAS, Antoni (1801), Memoria en la que se demuestra el método de precaver y curar el Rachitis [23 de juliol de 1801]. Ms. 89, Bundle 10, University of Barcelona.

BORRÀS, Antoni (1798), Acerca de la voz neutralizar el virus venéreo, Ms. 48, Bundle 7, University of Barcelona. 
BORRÀS, Francesc (1820), Tratado de patología teórico práctico, Vich, Imprenta nacional Ignacio Valls.

BOVER, Domènec (1800), Disertación sobre el uso de los globos aerostáticos aplicados a la medicina, 8 de Mayo de 1800, Ms. 78, Bundle 9, University of Barcelona.

BOVER, Domènec (1802), Discurso sobre el galbanismo, Ms. 99, Bundle 11. University of Barcelona.

BOVER, Domènec (1806), Sobre la fibra muscular. Ms. 136, Bundle 15, University of Barcelona.

BYNUM, William F.; PORTER, Roy (1985), William Hunter and the eighteenthcentury medical world, Cambridge, Cambridge University Press.

BLANCO, R.L. (1974) “The development of British Military Medicine, 1793-1814”, Military Affairs, Vol. 38, 1: 4-10.

BRAZIER, Mary, A.B. (1984) A History of Neurophysiology in the 17th and 18th Centuries, Nova York, Raven Press.

BUJOSA, Francesc (1983), “Gimbernat y Arbós, Antonio” In: LOPEZ PIÑERO, José María et al., Diccionario histórico de la ciencia moderna en España, Barcelona, Ediciones Península: 395-9.

CABRERA, Juan Rafael (1990), El libro médico-quirúrgico de los Reales Colegios de Cirugía Españoles en la Ilustración, Cádiz, Servicio de Publicaciones de la Universidad de Cádiz.

CALBET i CAMARASA, Josep Maria; CORBELlA i CORBELLA, Jacint (1981), Diccionari biogràfic de metges catalans, Barcelona, Fundació Fundació Vives Casajuana.

CARBONELL i BRAVO, Francesc (1805), Discurso que en la abertura de la escuela gratuita de Química establecida en la ciudad de Barcelona por la Real Junta de Comercio del Principado de Catalunya, Barcelona, Compañía de Jordi, Roca, y Gaspar.

CHAPTAL, M.J. (1816), Química aplicada a las artes, Barcelona, Brusi. 4 vols, vol 1 [edition in Spanish translated from the original work published in Paris in 1807 by Francesc Carbonell Bravo].

CARDONER i PLANAS, Antoni (1936), "Creació i Història del Real Colegio de Cirugía de Barcelona" In: Tres treballs premiats en el concurs d'homenatge a Gimbernat. Masnou (Barcelona), Societat de Cirurgia de Catalunya: 153-213. 
CASTELLVI, F. (2002), Narraciones Históricas Vol. IV, 1714-1724, Madrid, Fundación Francisco Elías de Tejada.

CIBAT, Antoni (1801), Censura leída en la junta de 30 de julio de 1801 acerca la disertación sobre el modo de precaver y curar la rachitis del Dr. Antonio Bas. Ms. 89-2, Bundle 10, University of Barcelona.

CIBAT, Antoni (1814-1815), Elementos de Física Experimental, Barcelona, Antonio Brusi. 2 vols.

CIBAT, Antoni (1798), Memoria o sea ensayo del trismus traumático, 12 de julio de 1798. Ms. 55, Bundle 7, University of Barcelona

CIBAT, Antoni (1799), Solución a las Objeciones que se hicieron a la memoria o ensayo sobre el trismus traumático que leyó en este Sabio Congreso en el año próximo pasado de 1798 y experimentos que corroboran el modo con que discurrí en aquella. Ms. 67, Bundle 8, University of Barcelona. [12 ${ }^{\text {th }}$ July 1799].

GUEREÑA, Jean Louis (1998), "Médicos y prostitución. Un proyecto de reglamentación de la prostitución en 1809: La "Exposición" de Antonio Cibat (17711811)", Medicina e Historia, 71:1-16.

FERRER, Diego. (1963), Biografía de Pedro Virgili: fundador restaurador de la cirugía en España, Barcelona, Colegio Oficial de Médicos de la Provincia de Barcelona.

FERRER, Diego (1968), Cirujanos del “Camp” en el siglo XVIII, Reus, Asociación de Estudios Reusenses.

GIMBERNAT i GRASSOT, Agustí, (1828), Sucinta Noticia del Sr. D. Antonio de Gimbernat escrita por su hijo don Agustín, Barcelona, Imprenta de Sierra y Martí.

GIMBERNAT i ARBÓS, Antoni (1773), Oración inaugural que para la abertura de los Estudios celebrada en el Real Colegio de Cirugía de Barcelona el día 5 de Octubre de 1773, Barcelona, Francisco Suria y Burgada.

GIMBERNAT i ARBÓS, Antoni (1793), Nuevo método de operar en la hernia crural, Madrid, Imprenta de la Viuda de Ibarra.

HODGSON, J.E. (1924), History of Aeronautics in Great Britain, Oxford.

HOLMES, F.L. (2000), "The "Revolution in Chemistry and Physics": Overthrow of a Reigning Paradigm or Competition between Contemporary Research Programs?" Isis, Vol. 91, 4:735-753.

LAÍN ENTRALGO, Pedro (1963), Historia de la medicina. Medicina moderna y contemporánea, $2^{\text {nd }}$ ed. Barcelona, Editorial Científico Médica, pp. 40-1. 
LAÍN ENTRALGO, Pedro (1950) La historia clínica, Madrid, Editorial Triascastela, 1998, facsimile edition, Madrid, CSIC.

KNIGHT, D. (2000), “Communicating Chemistry. The Frontier between Popular Books and Textbooks in Britain during the First Half of the Nineteenth Century": 187-206 in: LUNDGREN, A; BENSAUDE-VINCENT, B (eds.), Communicating Chemistry. Textbooks and their Audiences, 1789-1939, Science History Publications, Canton, MA.

LEVERE, Trevor H. (2001), Transforming Matter. A history of Chemistry from Alchemy to the Buckyball, USA, The Johns Hopkins University Press.

MARTÍNEZ VIDAL, Àlvar. (1999), "El Reial Col·legi de Cirurgia de Barcelona a l'Europa de la Il-lustració" in: CID, F. (ed.), Cinc Conferències sobre Pere Virgili, Barcelona, Fundació Uriach 1838.

MASSONS, Josep Maria (2002) El Reial Col·legi de Cirurgia de Barcelona, Barcelona, Fundació Uriach 1838

MORUS, Iwan Rhys (1998), Frankenstein's Children. Electricity, Exhibition, and Experiment in Early-Nineteenth-Century London, New Jersey, Princenton University Press.

NOLLET, Jean -Antoine (1746), Essai sur l'electricité des corps, París, Freres Guerin.

PÉREZ-PÉREZ, Núria (2004), "El Hospital General de Santa Creu frente al Real Colegio de Cirugía de Barcelona: La controversia surgida en torno al suministro de cadáveres para el anfiteatro anatómico de Gimbernat”, Medicina e Historia, 1: 1-16.

PÉREZ-PÉREZ, Núria (2007) Anatomia, química i fisica experimental al Reial Col·legi de Cirurgia de Barcelona (1760 - 1808), PhD dissertation, Philosophy Deparment at Universitat Autònoma de Barcelona. Published in TDX [Tesis Doctorals en Xarxa]. http://www.tdx.cat/TDX-1203107-162239 [last entry: 25th February 2010].

PERKINS, Benjamin Douglas (1800), The Efficacy of Perkin's patent metallic tractors in topical diseases on the human body and animals. [extracted from Bakken Library Catalogue, Minneapolis, EUA].

PI-SUNYER BAYO, Jaume (1936), “Antoni Gimbernat. Fundador de Col-legi de Cirurgia de San Carlos": 64-151, In Tres treballs premiats en el concurs d'homenatge a Gimbernat, Masnou, Societat de Cirurgia de Catalunya.

PORTER, Roy (1995), The Western Medical Tradition, 800 BC to AD 1800, Cambridge, Cambridge University Press, 1995.

RIERA PALMERO, Juan (1976), Cirugía española ilustrada y su comunicación con Europa, Valladolid, Universidad de Valladolid. 
ROBERTS, Lissa (1999), Isis, p. 686, "Science Becomes Electric. Dutch Interaction with the Electrical Machine during the Eighteenth Century", Isis: 680-714.

SALCEDO Y GINESTAL, Enrique (1928), Obras de Don Antonio de Gimbernat precedidas de un estudio biobibliográfico del mismo, 2 vols., Madrid, Imprenta Julio Cosano.

SAN GERMAN, Antoni (1800), Censura a la memoria que leyó Don Domingo Bover en 8 de mayo de 1800, Ms. 78-2, Bundle 9, University of Barcelona.

SELIGARDI, Raffaella (2001), "What is the electricity? Some chemical answers, 17701815”: 181-208 In: BERTUCCI, P.; PANCALDI, G., (eds.) (2001), Electric Bodies. Episodes in the history of medical electricity, Bolonya, Università di Bologna.

SCHAFFER, Simon (2004), "Fish and Ships: Models in the Age of Reason": 71-105, In: CHADAREVIAN, Soraya; HOPWOOD, Nick (2004), Models. The Third Dimension of Science, California, Stanford University.

STANSFIELD, Dorothy A. (1984), Thomas Beddoes M.D. 1760-1808: chemist, physician, democrat, Dordrecht, Reidel Publishing.

TOWNSEND, Joseph (1796), A Guide to Health being cautions and directions in the treatment of diseases designed chiefly for the use of students, Londres, Cox, Robinsons, Dilly, Murray and Highley, and Owen.

USANDIZAGA SORALUCE, Manuel (1964), Historia del Real Colegio de Cirugía de Barcelona. Barcelona, Instituto Municipal de Historia de Barcelona.

USANDIZAGA SORALUCE, Manuel (1956), Las Juntas Literarias del Real Colegio de Cirugía de Barcelona, Barcelona.

VICENTE GUILLÉN, Vicente (1982), Análisis de las memorias de las Juntas Literarias del Real Colegio de Cirugía de Barcelona, unpublished $\mathrm{PhD}$ dissertation, University of Barcelona.

ZARZOSO, Alfons (2004), Medicina i Il-lustració a Catalunya. La formació de l'Acadèmia Mèdico-Pràctica de Barcelona. Fundació Noguera. Lleida, Pagès Editors.

\section{Figure 1:}

[Anonymous] [subsequent to 1780], Regio Faetonte aerostático, Zaragoza, en la oficina de Blas Miedes, plate 50 x $35 \mathrm{~cm}$. Learning and Research Resources Center. Ancient Book Collection. University of Barcelona.

Aknowledgments 
I would like to express my deepest gratitude to the Centre for the History of Science (CEHIC) of the Autonomous University of Barcelona for supporting the correction of this manuscript into English. 